\title{
High SARS-CoV-2 protein S antibody titers in cord blood after COVID-19 vaccination during pregnancy: preliminary results
}

\author{
Wojciech Zdanowski ${ }^{1}$ and Tomasz Waśniewski ${ }^{1}$ \\ ${ }^{1}$ University of Warmia and Mazury in Olsztyn
}

May 5, 2021

\begin{abstract}
Background The coronavirus disease 2019 (COVID-19) pandemic has given rise to the need to develop a vaccine as quickly as possible. As pregnant women are at increased risk of contracting severe COVID-19, with higher mortality, it is essential to assess the safety of the vaccines administered during pregnancy. Methods The aim of this study was to determine the titer of specific maternal and cord antibodies against severe acute respiratory syndrome coronavirus $2 \mathrm{~S}$ protein after antenatal vaccination. The secondary objective was to evaluate the ratio of the umbilical cord to the maternal antibody titers. Patients included in the study were enrolled after undergoing voluntary vaccination against COVID-19 during pregnancy at different weeks of gestation. Their decision concerning vaccination was independent of the decision to participate in the present study. All patients analyzed in our initial study were vaccinated with the BNT162b2 mRNA COVID-19 vaccine. Results The results of the current study document high anti-S total antibody titers in cord serum at birth in all mother-infant pairs analyzed. Conclusions Our study suggests that maternal immunization may provide neonatal protection through transplacental transfer of antibodies.
\end{abstract}

\section{Hosted file}

High_SARS-CoV-2_protein_S_antibody_titers_in_cord_blood_after_COVID-19_vaccination_during_pregnancy_pre available at https://authorea.com/users/411269/articles/520860-high-sars-cov-2-protein-santibody-titers-in-cord-blood-after-covid-19-vaccination-during-pregnancy-preliminaryresults

\section{Hosted file}

Figure 3.pdf available at https://authorea.com/users/411269/articles/520860-high-sars-cov2-protein-s-antibody-titers-in-cord-blood-after-covid-19-vaccination-during-pregnancypreliminary-results

\section{Hosted file}

Table 1.pdf available at https://authorea.com/users/411269/articles/520860-high-sars-cov2-protein-s-antibody-titers-in-cord-blood-after-covid-19-vaccination-during-pregnancypreliminary-results 